\title{
SEIMURS GUSEINOVS
}

\section{DIEVA AUGI: HAŠIŠA UN KAN̦EPES LIETOŠANA SŪFIJU RITUĀLOS}

Halucinogēniem jeb apziņu paplašinošiem augiem ir svarīga loma cilvēku pieredzes vēsturē. To mēs novērojam vairākās religiskajās tradīcijās, kurās psihotropo vielu lietošana tiek uzskatīta par vienu no svarīgākajām rituālu sastāvdal̦ām. Piemēram, somas dzēriens agrīnā hinduismā - vēdas teksti apraksta šo dzērienu kā apziņu transformējošo vielu. Teorētiski soma varētu būt hašiša maisījums, kuru iekḷauj arī mūsdienu hinduisma rituālos. ${ }^{1}$ Viens no plaši izplatītiem rituāliem Rietumu pasaulē, kas nāk no Ziemel̦amerikas šamaņu tradīcijas, ir ajavaskas dzeršana. Šo psihotropo dzērienu parasti izgatavo no liānas koka, un tā funkcija "atklāt patieso pasauli"'. Âfrikā viens no svarīgākiem halucinogēniem ir iboga, ko parasti izmanto iniciācijas rituālos un saziņai ar mirušajiem senčiem. ${ }^{3}$ Psihotropo vielu iekl̦aušana religískos rituālos mēdz būt aprakstīta ļoti dažādi. Vienā gadījumā tie darbojas kā mediatori starp dievībām un cilvēkiem, otrā gadījumā tajos saskata ļaunuma iemiesojumu. Neatkarīgi no tā šādu vielu lietošanai vienmēr bija savdabīga funkcija.

Šajā rakstā mēs meklēsim iespējamos teoloǵiskos un vēsturiskos argumentus, ar kuriem islāma tradīcijā tiek pamatota psihotropo substanču lietošana gan rituālos, gan

1 James G. Lochtefeld, The Illustrated Encyclopaedia of Hinduism, Vol. II (New York: The Rosen Publishing Group, Inc., 2002), 659.

2 Richard Evans Schultes et al., Plants of the Gods: Their Sacred, Healing, and Hallucinogenic Powers (Vermont: Healing Arts Press, 2001), 62.

3 Ibid., 81. 
ikdienas dzīvē. Īpaši ņemot vērā, ka mūsdienās islāma pētniecībā šis jautājums netiek pētīts tik padziļināti. Kopumā mēs zinām, ka islāms attiecas noliedzoši pret jebkādām apreibinošām vielām, tajā skaitā alkoholu. Tomēr vēstures gaitā islāmā parādās tradīcija, kuras centrā bija indivīda mistiskā pieredze ar Dievu. Pamatā šī pieredze balstās neduālisma doktrinālā sfērā jeb wahdat ul-wujud (esamības vienotība). Tieši šis aspekts arī veido lielākās domstarpības starp ortodoksālo islāmu un sūfijiem. Tas dod iespēju sūfiju mistiķiem būt vienotiem ar Dievu caur iekšējo pieredzi, ko savukārt lielākā daļa islāma piekritēju uzskata par bid'a jeb herēzi. ${ }^{4}$ Tieši sūfisma doktrinālie aspekti piel̦auj šis tradīcijas piekritējiem iziet ārpus islāmā pieņemtajām normām. Atsvešinot sevi no islāma jurisprudences likumiem, sūfiji meklē jaunus un radošus cel̦us, caur kuriem viņi ir spējigi paust savu mīlestību pret Dievu un viņa radību. Lielākoties viņi pauž šo mīlestību caur mūziku, dzeju un dejošanu. Dejošana un dziedāšana ir garīgā prakse, kuras mērkiis ir pakāpeniski sasniegt ekstāzi (hal, wajd) un tuvināt indivīdu Dievam. ${ }^{5}$ Līdzīgas garīgās prakses mēdz arī ietvert hašiša ěšanu. Piemēram, daži no sūfiju literārajiem darbiem uzsver hašiša lietojumu rituālos kā palīgvielu, kas noved transa stāvoklī (wajd) un veicina indivīda apziņas pilnīgu nodošanos kontemplācijā par Dievu (fan'ā). ${ }^{6}$

Kaṇepe kā apreibinoša viela tika lietota Indijā un Irānā, jau sākot ar 1000. g. p. m. è. Tuvajos Austrumos to sāka izmantot islāma piekritēji tikai 1800 gadus vēlāk, divus gadsimtus pēc pravieša Muhameda nāves. Pravieša dzīves laikā (570-632) hašiša izgatavošana nebija aktuāla. Tas arī varētu būt par iemeslu, kāpēc pravietis Korānā stingri neaizliedz šī auga lietošanu. ${ }^{7}$ Jau sākot ar 9. gs., hašiša lietojums islāma pasaulē atrod savas saknes. Hašišu, kuru Indijā apzīmē ar bhang, sākotnēji lietoja persiešu un Irākas religisko grupu dalībnieki islāma impērijas austrumu perifērijā, teritorijā, kura robežojas ar šĩ auga izcelsmes vietu. ${ }^{8}$ Lìdz ar to austrumos ap 9. gs. beigām hašišs bija plaši izplatīts musulmaņu vidē. Ap šo pašu laiku islāma juridiskās sistēmas dibinātāji, galvenokārt šariati (al-Shāfiī) un hanafìti (Abū Hanīfa), norādỉja uz hašiša lietošanas bīstamību sabiedrībā. ${ }^{9}$

4 Mostafa Vaziri, Rumi and Shams' Silent Rebellion: Parallels with Vedanta, Buddhism and Shaivism (New York: Palgrave Macmillan, 2015), 6.

5 Shaheer Ellahi Khan, "Sufi Dance in Pakistan: Anthropological Insights on the Concept and Origin of Dhamal", Pakistan Association of Anthropology 27.2 (2015): 1641.

6 Danilo Marino, "Hashish and Food: Arabic and European Medieval Dreams of Edible Paradises", in Insatiable Appetite: Food as Cultural Signifier in the Middle East and Beyond, ed. Kirill Dmitriev et al. (Leiden: Brill, 2020), 193-194.

7 Gabriel G. Hanas, "Hashish in Islam 9th to 18th Century", Bull N.Y. Acad. Med., Vol. 58, No. 9 (1982): 814.

8 Ibid., 815.

9 Franz Rosenthal, "The Herb: Hashish versus Medieval Muslim Society", in Man versus Society in Medieval Islam, ed. Dimitri Gutas (Leiden: Brill, 2015), 182. 
Kaṇepes lietošana zoroastriešu tradīcijā
Sākot no 6. līdz 9. gadsimtam kaņepes lietošana islāma tradīcijā îsti nebija aktuāla. Neskatoties uz to, pastāv vairāki norādijjumi, kuri parāda kaņepes auga "mistisko" izmantošanu persiešu pasaulē vēlīnā zoroastriešu valdišanas laikā (5.-6. gs.). Pilnīgi iespējams, ka šāds auga lietojums pāriet no zoroastriešu tradīcijas islāmā. Piemēram, 19. gs. persiešu kultūras pētnieks Eduards G. Brauns (Browne) uzskata, ka kaņepes auga lietošana persiešu teritorijās sākās no zoroastriešu laikiem un turpinājās līdz pat 19. gs.: "Indijas kaņepe [..] bija pazīstama persiešu vidē jau no agrīniem laikiem, it īpaši ṇemot vērā, ka zoroastriešu sekotāji izceḷ rakstītās vietas Avestā, kurās ir iespraudumi par šī auga pielietošanu [..] Līdz pat šodienai šis augs ir plaši izplatīts sabiedrībā, [..] un tiek lietots kā iedvesmas avots spilgtām vīzijām un ekstāzēm."10 Šì auga psihotropā lietošana bija pazīstama arī sasaniešu valdnieka Husrova Parviza II valdīšanas laikā (590.623. g.). Paši zoroastrieši izcel Parviza netaisnīgo režīmu, kura dēḷ arī notika reliğijas un impērijas noriets. Botāniķis Viljams Dimoks (Dymock) izcel̦, ka kaņepes lietošana persiešu tradīcijā tiek novērota jau valdnieka Husrova I valdīšanai laikā (531.-579. g.). Tomēr paša auga lietojums šajā reǵionā bija krietni senāks. ${ }^{11}$ Vēlīnais zoroastriešu valdīšanas periods atspogulo, ka kaņepes augs bija aktuāls persiešu teritorijā jau 6. gs. sākumā. Tas varētu būt viens no iemesliem, kāpēc šis augs bija atzîts islāmā: "Kaņepe kā psihotropā viela bija nodota arābiem caur persiešiem."12 Savā veidā zoroastriešu un persiešu ietekme uz islāma attīstību radīja noslieci uz kaņepes lietojuma akceptēšanu islāma misticisma skolās. Ir zināms, ka islāms balstās zoroastriešu-jūdu-kristiešu tradīcijas turpinājumā, ${ }^{13}$ kas savukārt lauj mums saskatīt dažas iezīmes, kuras tika ienestas islāmā no zoroastrisma. Galvenokārt šādas iezīmes tiek novērotas starp persiešu musulmaņiem, piemēram, sūfijiem, asasīniem un ismailītiem. Šìs grupas samērā spēcīgi atspoguḷo zoroastrisma tradīcijas ietekmi, ieskaitot hašiša lietojumu ceremonijā. Jāñem arī vērā, ka musulmaņu iekarojumu laikā vairāki zoroastriešu sekotāji tika izsūtīti no Persijas vai tika konvertēti islāmā, līdz ar to kaņepes lietojums religiskajās ceremonijās ar laiku izzuda un kḷuva par pagrīdes lietu.

10 Edward G. Browne, "A Chapter From the History of Cannabis Indica", St. Bart's Hospital Journal (March, 1897): 82.

11 William Dymock et al., Pharmacographia Indica: A History of the Principal Drugs of Vegetable Origin, Met with in British India (London: Kegan, Paul, Trench, Trubner \& Co., Ld., 1892), 321.

12 Andrew Sherratt, "Alcohol and its alternatives: symbol and substance in pre-industrial cultures", in Consuming Habits: Global and historical perspectives on how cultures define drugs, ed. Jordan Goodman et al. (London: Routledge, 2007), 21.

13 Joseph Campbell, The Masks of God: Occidental Mythology (New York: Penguin Group, 1964), 421. 
Zoroastriešu tradīcijā kaņepe bija stingri aizliegta ārpus elitārās sabiedrības slāņa. Tās lietojums bija turēts noslēpumā un tika saistīts ar iniciācijas ceremoniju, kurā tiek izvēlēti izredzētie piekritēji. Tās mērḳis, līdzīgi kā Indijā, bija saistīts ar mistiskās pieredzes sasniegšanu. Zoroastriešu religíisko tekstu kopijas, kuras saglabājās no 5. gs., atsaucās uz substanci, ko dēvē par bhanga jeb persu valodā mang. ${ }^{14}$ Stāstijjumā tiek runāts, ka pats Zaratustra cel̦ošanas laikā nevarēja sekmīgi atrast sev jaunos piekritējus līdz brīdim, kad viņš sastapa valdnieku Vištaspu, kurš pārgāja zoroastrismā, izdzerot maǵisko dzērienu mang: "Vištaspa lietoja kañepi (bhang), lai sasniegtu ekstāzi: kamēr viņa ķermenis gulēja, viņa dvēsele celıjoja pa paradīzi." ${ }^{15}$

Korānā un hadītu literatūrā var atrast līdzīgu sižetu pravieša Muhameda cel̦ojumā uz paradīzi. Vairāki pētnieki uzskata, ka tieši šis notikums tika pārņemts no Arda Viraza grāmatas (Arda Wiraz Namag), ${ }^{16}$ kurā tiek runāts par svētā Viraza ceḷojumu uz elli un paradīzi pēc mang (kaņepes) ekstrakta dzēriena intoksikācijas. ${ }^{17}$

Mistisko celıjojumu Muhameds pieredzēja pusmiegā, kas liecina par saasinātu apziņas uztveri, citiem vārdiem, viņš atradās vieglas trauksmes stāvoklī. Šādu stāvokli Muhamedam izraisīja trīs izdzertās ūdens glāzes no Zemzem svētās akas, kuru dēl viņš bija spējīgs jāt uz lidojošā zirga Buraka. Dzeršana no trīs glāzēm tiek novērota arī zoroastriešu tekstos, kur lielākoties tiek minēti dažādi tēli, kas dzer brūvējumu no kaņepes ekstrakta, lai veicinātu dvēseles cel̦ojumu. Muhameda gadijumā šãds ceḷojums tiek novērots pēc viņa nonākšanas svētajā templī, pēc tam viņ̧̌ jāj uz Buraka, "līdz paradīzes vārtiem šḳērsojot sfēras..."18. lespējams, Muhameda lidojums uz paradīzi sasaucas ar "Arda Viraza mistisko ceļojumu, kuru viņš guva pēc psihotropo vielu intoksikācijas. Savā ziņā tas varētu liecināt par to, ka reǵionālie kulti saskatijja islāma atklāsmi caur savas tradīcijas prizmu vai arī ka islāma piekritēji saglabāja savu senču rituālus

14 Termins bhanga tiek lietots arī mūsdienās, lai identificētu kaṇepes augu, kurš nāk no Indijas. Chris Bennett, Liber 420: Cannabis, Magickal Herbs and the Occult (Walterville: Trine Day, 2018), 72.

Mircea Eliade, A History of Religious Ideas (Chicago: University of Chicago Press, 1978), 308.

16 Tieši Viraza cel̦ošanas konteksts ir interesants. Vinš tika sūtīts, lai a) apstiprinātu zoroastriešu mācību par neredzamo pasauli un b) gūtu pārliecību par zoroastriešu kopienas rituālu efektivitāti. Šajā stāstā parādās Viraza dievbijība saistībā ar viṇa religisko nepārliecību. No visas kopienas pārstāvjiem, kuri savācās pie uguns Ādur Farnbaga tempḷa, tieši Virazs savas tikumības dēl bija izraudzīts, lai izdzertu narkotisko dzērienu mang. Kamēr Virazs septiñas dienas bija bezsamañā, viña māsas un citi kopienas pārstāvji lūdzās, citējot Avestas un Zanda tekstus. Kad Viraza dvēsele atgriezās ķermenī, vinšš izstāstīja savu pieredzi pārējiem. Šĩ pieredze lielākoties atspogul̦o grēcinieku sodus ellē un tikumīgo atlīdzību paradīzē. "Ardā Wỉrāz", Encyclopaedia Iranica, August 11, 2011, https://iranicaonline.org/articles/arda-wiraz-wiraz (skatīts 12.11.2020.)

17 Bennett, op. cit., 73.

18 Herbert Henry Gowen, “Dante and the Orient”, The Sewanee Review, Vol. 32, No. 3 (Oct. 1924): 438. 
jaunpieņemtajā tradīcijā. Šīs tradīcijas savukārt tiek iesakṇotas islāma misticisma skolās, piemēram, šiitu gnostiķu un sūfiju tradīcijās" ${ }^{19}$. Muhameda nakts celojojums tiek arī pārstāstīts 17. gs. "reliǵiju skolas" (Dabestan-e Madaheb) grāmatā, iekḷaujot detalizētu aprakstu, kurā pats Muhameds sagatavo sev maisijjumu no indiešu kaņepes auga (bhang). ${ }^{20}$

Dabestan-e Madaheb teksts atspoguḷ stāstu par pravieša iepazišanos ar kaņepes augu un tā lietojumu Hašim klanā (Muhameda pirmsteči): "Pastāv viena grupa starp hinduistiem, kuri sevi dēvē par musulmaņu sūfijiem (Musslam-Sofis). Kopā ar tradicionālajiem sūfiju piekritējiem viņi vienprātīgi atbalsta stāstu, kurā "pravietis Muhameds, staigādams kopā ar enggeli Gabriēlu, nonāca līdz vietai, kur varēja sadzirdēt pūḷa trokšñus. Gabriēls teica: "Tas ir baudas slieksnis; ieej iekšā mājā." lenākdams iekšā, pravietis ieraudzīja četrdesmit kailus cilvēkus sēdus stāvoklī (kā viņi nākuši no savas mātes klēpja) un kalpus, kuri viņus apkalpoja. Kamēr sasmalcinātā kaņepe nebija pasniegta, cilvēki neatsaucās uz pravieša teikto. Kad augs tika nolikts uz grīdas, kailiem cilvēkiem nebija drēbju, ar ko izspiest un attîrìt auga ekstraktus; šajā brīdī pravietis noṇēma no savas galvas turbānu un izspieda kaņepes auga sulu. Pēc tam vinga turbāns kḷuva zaḷš (Hašima klana krāsā). Kad Muhameds sniedza viniiem šo pakalpojumu, cilvēki bija sajūsmā un savā starpā teica: "ledosim šim Dieva sūtītajam cilvēkam bhang augu, lai viņš varētu iepazīt Visuvarenā noslēpumus." ${ }^{21}$

\section{Termins "hašišs" islāma tradīcijā}

Būtu svarīgi atzīmēt, ka plaši izplatītais termins "hašišs" pats par sevi ir tikai apzīmējums. Šim vārdam kā tādam nav nekādas konkrētas saistības ar pašu kaņepes augu.

Šis termins tikpat labi varētu būt lietots, lai raksturotu zāli, ko izmanto lopbarībai, vai augus, ko lieto medicīnā. Mēs îsti nevaram pateikt, kurš no visiem hašiša apzīmējumiem veicināja tā saistību ar kaņepes augu lietošanu..$^{22}$ Jebkurā gadījumā ir skaidri zināms, ka šīs psihotropās vielas termins kluva populārs un bija plaši lietots islāma pasaulē.

Arābu valodā vārds hašišs ش شيشحashish kopumā apzīmē sausu zāli jeb vienkārši augu. Šĩ vārda sākotnējais lietojums attiecās uz augu produktiem no 7. līdz 13. gs.

19 Frederick R. Dannaway, "Celestial Botany: Entheogenic Traces in Islamic Mysticism”, Essay (2006), 6.

20 Viens no svarīgākajiem pseidozoroastriešu tekstiem. Pamatā teksts runā par reliǵijām 17. gs. Indijā. lespējams, grāmatas autors bija sūfijs, kas praktizēja zoroastriešu doktrīnu. "Dabestan-e Madaheb”, Encyclopaedia Iranica, November 10, 2011, https://iranicaonline.org/articles/dabestan-e-madaheb (skatīts 14.11.2020.)

21 Bennett, op. cit., 73.

22 Rosenthal, The Herb: Hashish versus Medieval Muslim Society, 154. 
Ibn al-Baitārs 13. gs. savā darbā Jāmi izceḷ, ka hašišs ir ēǵiptiešu termins, kas attiecas uz trešo kaņepes šķirni, dēvētu par "indiešu kaņepi” (al-ginnab al-hindî), kuras lietojums izraisa apreibinošu un eiforisku iedarbību. Līdz ar to nav nekāda pamatojuma šaubīties, ka arābu termins hašišs nāk no indiešu kaņepes auga šķirnes, ko mūsdienu botāniķi dēvē par cannabis sativa indica - otrā kaņepes šķirne, kura ietver lielu tetrahidrokanabinola (THC) daudzumu, kas ir galvenā kan,epju auga psihoaktīvā viela. ${ }^{23}$

Viens no izplatītākajiem nosaukumiem, kas apzīmēja hašišu, bija al-khadrā jeb zaļais. Šāds apzīmējums bija īpaši populārs dzejnieku starpā. Lielākoties to izmantoja kā metaforu. Protams, pastāv dažādas interpretācijas saistībā ar hašiša zaļo krāsu. Piemēram, hašiša smēḳētāja bālo ādas krāsu, līdzīgi kā cilvēkam, kura vaigi kḷūst sarkani no vīna. Interesants gadījums tiek novērots viduslaiku islāma tekstos, kur kaņepes augs tiek personificēts ar kādu svēto sūfiju. ${ }^{24}$ Piemēram, 16. gs. sūfiju dzejnieks Fuzuli savos rokrakstos atzīmē, ka terminam "hašišs" un svētā mistiķa al-Khizr vārdam ir kopīgs epitets - zaḷais. Līdz ar to sūfisma piekritēji atsaucās uz hašiša lietošanu kā "tikšanos ar svēto zalıo Khizru"25. Arī 1894. gadā Kembels (J. M. Campbell) savā esejā On the Religion of Hemp atzīmē svētā Khizra attiecības ar kaņepes augu: savā uzticībā bhangam ar godbijību, nevis pielūgšanu, kura tiek veltīta tikai Dievam, Ziemeļindijas musulmanis (kopā ar šaivītiem) pievienojas himnai, lai slavētu bhangu. Islāma reliĝijas piekritējam bhanga svētais gars nav visvarenā gars, bet gan pravieša Khizra jeb Elijas gars. Tas, ka bhanga augs ir svēts pašam Khizram, ir tikai dabiski, jo pats Khizrs ir ūdens aizstāvis (patrons). Khizr nozīmē 'zaļš̌, līdzīgi kā atsvaidzinoša bhang dzēriena krāsa. Tāpēc urdu dzejnieks dzied: "Dzerot svaigo bhangu, es pielīdzinu tās krāsu svaigajai gaismai, kura krīt uz jūsu jaunības bārdas." Uz ko svētais Khizrs atbild: "Lai šis dzēriens nes jums prieku."26

Dažādi nosaukumi, kas apraksta hašišu, lielā mērā arī balstās uz tā lietošanas efektu. Piemēram, "tas, kurš sagremo ēdienu" (hādim al-aqwā) vai "domu iedvesmotājs" (bā'ithat al-fikr), "domu kumoss" (luqayamat al-fikr). Turkiem nosaukums "noslēpumi" (esrār) bieži vien asociējās ar hašiša spēju pavērt jaunus "mentālās uztveres līmeņus"27. Ma'lūm ir samērā populārs apzīmējums hašišam. Tāds nosaukums bija izplatīts starp sūfijiem, jo tas apzīmēja "atmaksu" par ciešanām nabadzīgo sūfiju dzīvē. ${ }^{28}$

\footnotetext{
23 Marino, op. cit., 191.

24 Rosenthal, op. cit., 286.

25 Ibid., 170.

26 J. M. Campbell, "On the Religion of Hemp", in Indian Hemp Drugs Commission, Vol. 3, ed. M. Young, et al. (Simla: Government Central Printing Office, 1894), 252.

27 Rosenthal, op. cit., 158.

28 Ibid., 160.
} 
šanā. Lietojot hašišu, indivīds nevarēja tikt uzskatīts par religisku herētiķi, kamēr vīna dzeršana tikai asociēta ar neticību un netiklību. Lielākās poētiskās debates par hašiša lietošanas priekšrocībām, salīdzinot ar vīnu, tiek novērotas starp sūfiju skolām. Agrāk minētais 16. gs. sūfiju dzejnieks Fuzuli uzrakstija veselu traktātu par bhanga un vīnu lietošanu. Pēc Fuzuli domām, vīns ir kā energiisks māceklis, kurš vēlas sadedzināt pasauli, kamēr hašišs ir pats sūfiju skolotājs. Vīns parāda ceḷu uz sūfiju skolotāja mītni, bet hašišs ir pats patvērums. Fuzuli arī norāda uz stāstu, kurā viens no sūfiju mācekḷiem pēc regulāras hašiša lietošanas sasniedza absolūto vienību, pēc kuras viṇam vairs nevajadzēja skolotāja palīdzību. ${ }^{29}$

Neskatoties uz to, ka vīna un hašiša maisījuma lietošana tika uzskatīta par k̦ecerību, tā bija samērā populāra parādība viduslaiku islāmā. Vīna un hašiša maisījumu parasti varēja aț̣auties turīgie sabiedrības locekḷi, kamēr tīru hašišu lietoja zemākais slānis. lecienītie islāma zinātnieki uzskatīja, ka šāda dzēriena lietošana ir pieḷaujama: "Šis dzēriens tiek slavēts kā iedvesmas avots, kur kaņepe ir izcila ar savu slinkumu un vīns ar savu enerǵiju." ${ }^{30}$ Līdzīgā veidā uz to atsaucās Ibrahims al Mimārs (1348), kurš to dēvēja par "amata meistaru":

$$
\begin{aligned}
& \text { Vinšš sajauca hašišu un vīnu, } \\
& \text { un uz vietas noslīka reibumā, kḷūdams apjucis un strīilīgs. } \\
& \text { Un es jautāju: kas ir šis negaidītais notikums? } \\
& \text { Kad viņš atkal bija skaidrā, viņš man atbildēja: } \\
& \text { Esi iecietīgs pret savu brāli, kad vingš jauc vīnu ar hašišu. }
\end{aligned}
$$

$\begin{array}{ll}\text { Hašasīni jeb asasīni } & \text { Hašiša lietošana islāmā ir saistīta ar persiešu un Irākas } \\ \text { religiskām grupām, kuras lielākoties atradās Abāsīdu }\end{array}$ impērijas austrumu perifērijā, uz robežas ar auga izcelsmes vietu. Spilgts piemērs tādām grupām ir hašasīni, vairāk zināmi kā asasīni jeb slepkavas, kuri pamatā piederēja pie viena no Alamutas ismailītu skolas atzariem. Jāñem arī vērā, ka asasīnu kults ir stipri ietekmējies no zoroastriešu tradīcijas. Al-Busti 1029. gadā izceļ, ka ismailìtu doktrinālie aspekti ir radušies no "irāñu duālisma un zoroastrisma pamatiem"32. Asasīni atspoguḷo vienu no islāma tradīcijas atzariem, kura pamats balstās pirms islāma

\footnotetext{
29 Peter Lamborn Wilson, Scandal: Essays in Islamic Heresy (New York: Autonomedia, 1988), 93.

30 Rosenthal, op. cit., 199.

31 Ibid., 199.

32 Farhad Daftary, Ismaili Literature: A Bibliography of Sources and Studies (London: I. B. Tauris Publishers, 2004), 176.
} 
eksistējošajā kultā. Citu musulmaņu vidē viņi bija pazīstami kā hašasīni jeb hašiša ēdāji. ${ }^{33}$ 13. gs. musulmaņu vēsturnieki pamatā lieto terminu hašasīni, atsaucoties uz sīriešu (hashīshiyya) un persiešu (hashīshīs) ismailītiem. ${ }^{34}$ Jau sākot ar 8. gs., ismailīti lietoja kaņepes augu, jo "tā iedarbība palīdzēja realizēt kopienas ceremonijas"35.

Nosaukums asasini jeb slepkavas kḷuva pazīstams Eiropā 12. gadsimtā krustnešu dēl, kuri to asociēja ar ismailītu drosmi slepkavot savus politiskos oponentus "pateicoties hašiša spēkam" ${ }^{36}$. Kopumā liela daļa pētnieku uzskata, ka grupas nosaukums hašasins ir cēlies no arābu vārda ḥashīsh, kas apzīmē zāli, vai no persiešu vārda hasasin, kas apzīmē dziednieku vai zāļu tirgotāju. Pastāv arī iespēja, ka šāds nosaukums ir cēlies no slavenā Omāra Haijāma bērnības drauga, vārdā Hassan-i Sabbah, kurš bija pazīstams kā "kalna vecis” jeb "hašiša turētājs". Tiek uzskatīts, ka Hasans ḳēra un apreibināja savus jaunos piekritējus ar hašiša maisījumu, turēdams viņus savā cietokšña dārzā. Tur savukārt vienīgais mērksis bija mīlēties ar skaistām sievietēm. Caur šo pasaulīgo paradīzi Hasans nodrošināja savu piekritēju uzticību un paklautību bīstamās misijās, solot viņiem, ka pēc viņu atgriešanās no dotā uzdevuma "eņgelı ievedīs viņus paradīzē" ${ }^{37}$. Viennozīmīgi Hasans bija ismailītu reliĝiskās grupas vadītājs, kurš aizsargāja persiešu robežas Alamutas regionā. Fakts, ka viņš apmācīja savus sekotājus bezbailīgi cīnīties, arī nav aplams. 12. gs. vairākus arābu sultānus, kā arī dažus krustnešu vadoņus nogalināja Hasana sekotāji. ${ }^{38}$

Hašasīni uzskatīja sevi par svēto zināšanu un tradīciju turētājiem, tas parādās arī citos apzīmējumos, kuros viņi sevi dēvēja. Piemēram, batiniya (tulkojumā - ezotēriķi) jeb, kā vinus dēvēja kritiķi, malahida, herētik̦i. ${ }^{39}$ Ismailītu tradīcijā kaņepe bija viena no svarīgākajām sastāvdal̦ām, kura nodrošināja piekl̦uvi šīm zināšanām. Pirms kaņepe kļuva populāra islāma sabiedrībā, tās lietošanu ismailītu piekritēji turēja noslēpumā, līdzīgi kā zoroastriešu gadījumā - ismailītu valdīšanas laikā apreibinošo vielu lietošana vēl nebija izplatīta musulmaņu apdzīvotajās valstīs. Zināšanas par kaņepes lietošanu nāca islāma sabiedrībā no austrumu reǵioniem, visdrīzāk no Indijas. Un tikai tad tās izplatība kḷuva populāra Mezopotāmijas, Sīrijas, Mazāzijas un Ėǵiptes musulmaņu vidē. Savukārt ismailīti, kuru doktrīnā var atrast dažas līdzības ar Indijas relig̛iskajām

\footnotetext{
33 Bennett, op. cit., 82.

34 Daftary, Ismaili Literatur, 88.

35 Dymock, op. cit., 321.

36 Phyllis Palgi, "The Traditional Role and Symbolism of Hashish among Moroccan Jews in Israel and the Effect of Acculturation", in Cannabis and Culture, ed. Vera Rubin (Berlin: De Gruyter Mouton, 1975), 210.

37 Hanas, op. cit., 815.

38 Ibid., 816.

39 Bennett, op. cit., 84 .
} 
tradīcijām, saņēma zināšanas par kaņepes auga mistisko lietošanu agrākā laika posmā un turēja to noslēpumā kā vienu no saviem spēka avotiem. To apstiprina arī fakts, ka viens no slavenākajiem arābu rakstniekiem, kurš ar veltijumu persiešu ismailītam uzrakstija ievadu par kaņepes auga dzēriena sagatavošanu ēgiptiešiem..$^{40}$ Visdrīzāk sākotnējais hašiša lietojums islāmā varētu būt saistīts ar iniciācijas ceremonijām, kurās tika izmantota apreibinošā substance, lai nodrošinātu mistisko pieredzi, nevis veiktu organizētas slepkavības. "Asasīnu skolā kaņepes maisījums tika lietots, lai sasniegtu vīiijas par paradīzi. Tās funkcija nekādā veidā nebija saistīta ar "drosmi slepkavot" un agresiju. Tieši otrādi, tā deva tradīcijas sekotājiem nelielu ieskatu par augstākās realitātes sfēru." ${ }^{41}$

\section{Korāns un hašiša lietojums}

Neatkarīgi no tā, kā kaņepes augs ienāca islāma pasaulē, tā lietošana izraisīja dažādu attieksmi - gan slavinājumu, gan nicinājumu. Salīdzinājumā ar alkoholu kaņepes lietošana nekādā veidā netika Korānā aizliegta, līdz ar to sabiedrības attieksme pret šo substanci mēdza būt loti atšķirīga. Agrīnie musulmaņu komentatori neizslēdza faktu, ka hašišs netiek pieminēts Korānā vai pravieša tradīcijā. Viņi arī nevarēja atrast tiešas atsauces uz to četru islāma juridisko skolu dibinātāju vārdos. Agrīnie autori Šafite al-Muzanī (878. g.) un Hanafite at-Tahavi (933. g.) tiek citēti kā psihotropo vielu lietošanas oponenti, tomēr ir skaidri zināms, ka savos darbos viņi nelieto tādu terminu kā hašišs. Pastāv liela iespējamība, ka viņi arī neizmantoja nekādus citus apzīmējumus, kas attiektos uz kaņepes lietošanu, izņemot, ja tas tika izprasts ar terminu banj. Bieži vien komentatori arī centās sasaistīt terminu hašišs ar slaveno Hanafita al-Kuduri (1037. g.) likumu apkopojumu, lai gan pats darbs nekādā veidā neatsaucas uz vārdu hašišs vai banj. Az-Zarkaši, atsaucoties uz Abu Išak aš-Širāzī (1083. g.) darbu at-Tadhkirah fị l-kilāf, vēlējās atspogulot, ka Širāzī izmantoja terminu hašišs. Tādā gadījumā aš-Širāzī, kurš dzīvoja Bagdādē, būtu viens no pirmajiem autoriem, kurš iekl̦āva šo terminu savā darbā, izceḷot hašiša likumīgo problēmu. Pirmā tiešā atsauce uz vārdu hašišs (hashishiyah) tiek novērota tikai 1123. gadā saistībā ar ismailītu tradīciju. ${ }^{42}$

Kopumā Korāna komentatori varēja brīvi interpretēt ši auga nepieciešamību vai kaitīgumu sabiedrībai. Šādas neskaidrības dēl kaņepes auga lietojums islāmā vienmēr paliek atvērts diskusijām. Protams, tādas minoritāšu grupas kā asasīni un sūfiji vienmēr

\footnotetext{
40 Joseph Von Hammer, The History of the Assassins: Derived from Oriental Sources (London: Smith and Elder, Cornhill, 1835), 235.

41 Michael Aldrich, "Cannabis and its Derivatives", in High Times Encyclopaedia of Recreational Drugs, ed. Andrew Kowl (New York: Stonehill Publishing Company, 1978), 123.

42 Rosenthal, op. cit., 175-176.
} 
bijušas siltās attiecībās ar hašiša lietojumu, it īpaši ñemot vērā, ka viņu pašu pravietis bija viens no cilvēkiem, kurš, iespējams, atbalstijja tā lietošanu. Arī spilgtais dažādu epitetu klāsts terminam hašišs (piemēram, svēta zeme jeb Jeruzaleme; tas, kas vieno sirdi; skaistais; mierinātājs; pāva aste) atspogulı plašu auga lietojumu arābu pasaulē.

Korāns ir samērā neitrāls attiecībā pret psihotropām vielām kā tādām. Tas ietver terminu khamr jeb apreibinošā viela, konkrēti, alkohols. Daži uzskata, ka termins khamr ir salikts termins, kurš nozīmē visas apreibinošās vielas, neskatoties uz to, ka specifisks konteksts, kurā runa ir par kharm, visos trijos Korāna pantos tiek attiecināts uz alkohola dzeršanu. Al-Tabari atzīmē, ka khamr ir jebkurš dzēriens, kas apreibina prātu, piemēram, dzērieni, kuri bija aktuāli pravieša laikā - kharm (vīns), bit (vīns no medus) un mizr (alus). Tomēr islāma sākuma periodā nav nekādu negatīvu liecību pret hašiša, driǵenes un opija lietošanu. Kā arī Korānā nav atsauču, kuras atspoguḷotu šo substanču bīstamību sociālajā un politiskajā vidē..$^{43}$ Tieši otrādi, pastāv plašs literatūras klāsts, kurā tiek aprakstītas kaņepes auga ārstnieciskās īpašības. ${ }^{44}$ Ārsti uzskatīja kaņepi par plaši lietojamu ārstniecisko medikamentu terapijas nolūkos. ${ }^{45}$ Pamatā to ēda, nevis smēķēja, tas arī atviegloja gremošanas trakta darbību un nomierināja prātu. ${ }^{46}$ Kaṇepju terapeitisko īpašību dēl arābu medicīnā tās lietoja kā diurētiķus (urīndzenoši līdzeklị), antiepileptiķus, pretiekaisuma līdzekḷıs, pretsāpju zāles utt. ${ }^{47}$ Sekulāras zināšanas par kaņepes lietojumu tika bagātinātas ar musulmaņu reliǵisko pētnieku debatēm. Viṇi pamatā diskutēja par tās legalizēšanu. Tā kā nebija aizlieguma par kaņepes izmantošanu, medicīnā izvērstās debates deva pārliecību un iedrošināja rakstīt par tās pozitīvajām īpašībām. Aizliegumi lietot kaņepi kḷuva aktuāli tikai tajā brīdī, kad valsts pārstāvji saskatijja to kā sociālu problēmu. Neskatoties uz to, ka pētnieki nevarēja atrast agrīnās atsauces uz kaṇepes lietošanu kopš pravieša Muhameda dzives laika (571.-632. g.) ${ }^{48}$, daži islāma juristi saskatīja analogiju ar alkoholu, lai pamatotu psihotropo vielu lietošanas aizliegumu.$^{49}$ Arī vairāki teologi centās izvirzīt likumus pret hašišu, tomēr neviens no viņiem nebija atzīts pēc autentiskās pēctecības līnijas (silsilah). Kāds pravietis esot

43 Ali Mansur, "Perspectives on Drug Addiction in Islamic History and Theology", Religions 5 (Sep. 2014): 915.

44 Rosenthal, op. cit., 174.

45 Sami Hamarneh, "Pharmacy in Medieval Islam and the History of Drug Addiction", Medical History 16 (1972): 228.

46 Rosenthal, op. cit., 157.

47 Indalecio Lozano, "Therapeutic Use of Cannabis sativa (L.) in Arabic Medicine", Journal of Cannabis Therapeutics Vol. 1.1 (2001): 69.

48 Maziyar Ghiabi et al., "Islam and Cannabis: Legalisation and Religious Debate in Iran", International Journal of Drug Policy 56 (2018): 122-123.

49 Rosenthal, op. cit., 208. 
teicis: "Atnāks tā diena, kad cilvēki sāks lietot vielu, vārdā bang. Es atturos no tādiem cilvēkiem, un viņi no manis." ${ }^{0}$ Cits piemērs: "Sveiciniet jūdus un kristiešus (nasiri), bet tikai ne bang smēḳētājus." ${ }^{11}$ Abi varianti nāk no laika, kad hašiša lietojums guva popularitāti Tuvajos Austrumos.

Kopumā pret jebkādiem religískiem aizliegumiem hašiša aizstāvji vērsās ar faktu, ka Korāns un Muhameds neaizliedz narkotisko vielu lietošanu. Viena no slavenākajām rindkopām, kura labi izcel šo problēmu, ir:

$$
\begin{aligned}
& \text { Mīlāā inteligence un saprāta cilvēki, } \\
& \text { Hašišs ietver sevī manas kāres jēgu. }
\end{aligned}
$$

Vini to ir pasludinājuši par aizliegtu bez jebkāda pamatojuma tradīcijās un saprātā.

Sludināt aizliegumu par to, kas nav aizliegts, ir aizliegums. ${ }^{52}$

Musulmaņu pētnieki cītīgi uzsāka meklēt risinājumus hašiša lietošanas aizliegumam brīdī, kad tā aktualitāte sāka ietekmēt sociālo sfēru. Vini iedalīja visas darbības piecās kategorijās, zināmas kā tiesību normas: a) wajib - akūta darbība jeb palīdzība, kura ieklauj kaut kādas nelikumīgas normas; b) haram - aizliegums; c) halal - piel̦aujamā darbība. Savukārt tās darbības, kuras ir piel̦aujamas, ir d) mandub - ieteicamas vai e) makruh - atļautas, bet sabiedrībā neieredzētas..$^{53}$

Kopumā visa diskusija balstās tajā, ka Korānā un islāma juridiskās skolas pamatos hašiša lietošana netiek pieminēta. Šie avoti stingri aizliedz kharm (vīna) lietošanu, kas savukārt vēlākā laikā tika interpretēts kā jebkura apreibinoša viela: "Ak, ticīgie! Patiešām, reibinoši dzērieni, laimes spēles, akmens ziedoklı̣i un zīlēšanas bultas nav nekas cits kā sātana pretīgas izdarības. Atturieties no tiem, ja gribat, lai jums veicas. Ar apreibinošiem dzērieniem un laimes spēlēm sātans grib sēt jūsu vidū nesaskaņas un ienaidu un atraut jūs no Dieva pieminēšanas un lūgšanām. Vai tad jums labāk no tā neatturēties?" (5:90-91) $)^{54}$

Pravieša dzīves laikā kharm pamatā apzīmēja vīnu, un tikai trīs gadsimtus vēlāk, pēc viņa nāves, islāma likumdevēji sāka interpretēt terminu kharm saistībā ar jebkuru substanci, kura apskurbina prātu. Tomēr juridiskās skolas interpretācija nekad nebija saskañā ar termina populāru lietojumu sabiedrībā, ko mēs redzam arī mūsdienās, kharm pamatā tiek izprasts kā vīns jeb alkohols. Musulmaņiem aizliegumā pret

50 Ghiabi, Islam and Cannabis: Legalisation and Religious Debate in Iran, 123.

51 Ibid., 123.

52 Rosenthal, op. cit., 236.

53 Joseph Schacht, An Introduction to Islamic Law (Oxford: Clarendon Press, 1982), 121.

54 Korāns, tulk. Imants Kalniņs (Rīga: Medicīnas apgāds, 2011), 120-121. 
raudzētiem dzērieniem nebija iekḷauts hašiša lietojums. Neskatoties uz domstarpībām, trīs no četriem (mālikītu, šãfiītu un hanbalītu) islāma juridiskās skolas likumdevējiem klasificēja hašišu kā apreibinošo vielu un aizliedza tā lietošanu sunnītu tradīcijas pārstāvjiem. ${ }^{55}$ Ceturtā skola (hanafìtu) izmantoja šaurāku apzīmējumu, kur hašiša lietošana ir pieļaujama mazos daudzumos, kā arī ārstnieciskos nolūkos. Az-Zarkaši 1360. gadā to apraksta šādi: "Jebkāda intoksikācija ar vīnu ir aizliegta, jo tas ir nešķists dzēriens. Kamēr hašišu, kurš ir šḳists, var lietot, tikai ne apreibināšanās nolūkos." ${ }^{56}$ Cits jurists to apraksta līdzīgā veidā: "Salīdzinājumā ar vīnu, hašišs tiek lietots medicīnā. Sodīšana uz to neattiecas. Ëst hašišu mazos daudzumos nav aizliegts tik ilgi, kamēr tas neapreibina prātu un mañas." ${ }^{57}$ Kā redzam, kañepes ārstnieciskās īpašības ietekmēja juridiskās skolas pārstāvju attieksmi pret to lietošanu. N̦emot vērā, ka likums neaizliedz cilvēkiem bojāt savu fizisko veselību un garīgo stāvokli, musulmaņu juristi bija satraukti par iespējamām fiziskām un mentālām kaitēm no narkotisko vielu lietošanas. Tomēr arguments, ka hašišs spēj izraisīt hroniskas k̦ermeņa un prāta slimības, nebija objektīvi apstiprināts. Beigu beigās lielākā juristu daļa bija par hašiša aizliegumu, jo "visi ortodoksālā islāma pārstāvji atbalstija ideju, ka jebkura substance, kas ietekmē cilvēka apziņu, islāmā ir aizliegta"58.

Lai gan islāma jurisprudence sekmīgi apliecināja kaṇepes aizliegumu, tomēr tai neizdevās ierobežot tās lietošanu sabiedrībā. Varētu teikt, ka uzvara bija pirriska. Viṇiem nācās samierināties ar sabiedrības uzskatu, kuru reliǵiskie likumi pilnībā kontrolēt nespēja galvenokārt tāpēc, ka psihotropo vielu lietošanas nelikumība ilgu laiku tika ignorēta. Tādējādi pārliecība par to, ka pravietis aizliedza tikai alkoholu, iesakņojās musulmaņu sabiedrībā.

Hašiša lietošana sūfismā Centrālais konflikts, kas atspoguḷojās islāma religiozitātes formēšanas periodā, balstās attieksmē pret pasaules pieņemšanu vai tās noraidī̌sanu. Spēcīga tendence noraidīt pasauli, balstoties visuvarenā Dieva konceptā un postulējot viņa realitāti kā "svešo jeb nākamo", vienmēr tika nostādīta pretim vienlīdz spēcīgai tendencei - Dieva radītās pasaules pieņemšanai, kurā ir iespējama pestī̌šna caur morāli pareizu darbību un attieksmi sabiedrībā. Arī Korāns un sunnas izcel ššs un nākamās pasaules konstrukcijas. ${ }^{59}$ It īpaši Korāns

55 Hanas, op. cit., 825.

56 Ibid., 825.

57 Ibid.

58 Ibid.

59 Ahmet T. Karamustafa, God's Unruly Friends: Dervish Groups In the Islamic Later Middle Period 1200-1550 (Utah: University of Utah Press, 1994), 56-58. 
nodrošina musulmaņus ar pantiem, kas aicina ticīgos izvairīties no istās pasaules un virzìt skatienu uz citu pasauli. Piemēram, Dievs palielina dodamo, kam vēlas, un arī samazina. Un viṇi priecājās par šis pasaules dzīvi. Bet šis pasaules dzīve, salīdzinot ar Nākošo dzīvi, ir vien ātri pārejošs prieks. (13:26) Vai Un šis pasaules dzìve nav nekas cits kā izpriecas un rotalas. Un patiešām, Nākošās dzīves mājas ir tā patiesā dzìve. (29:64) ${ }^{60}$ Savukārt citi Korāna panti izcel, ka citpasaules guvumi ir atkarīgi no indivīda sociālajiem sasniegumiem. Konflikts starp šīm divām atšķirīgajām attieksmēm sasniedza savu kulmināciju ap 9. gs. Kamēr îstās pasaules slavinošã sabiedrība bija aizņemta ar legālas sistēmas dibināšanu (piemēram, al-Šafiī, 767.-820. g.), pasaules noraidītāji koncentrējās uz tawakkul (pilnīgā paļaušanās Dievam) doktrīnu. Tawakkul doktrīnā, kuras sākotnējā ideja tiek atspogulota Šakik Balkhi domā, attīstības gaitā aizvietoja negatīvi noraidošu pasaules redzējumu ar pozitīvu skatījumu. Dievbijība un bažas par pēcnāves dzīvi tika aizvietotas ar pilnīgu atdevi Dieva gribai. Neskatoties uz saasināto kritiku no legālās skolas pārstāvju puses, askētiskais dzīvesveids, kurš bija raksturīgs tawakkul doktrīnas sekotājiem, aizrāva arī kultūras dzīves jomas pārstāvjus, kas savukārt palīdzēja uzturēt tās aktualitāti. Par to arī liecina zuhdiyyat dzejas žanrs, kas balstās askēzes tēmās. ${ }^{61}$

Tieši šajā vēstures posmā islāmā radās sūfisms. Savā jaunās dievbijības formātā tas palīdzēja novērst plaisu starp dievbij̄̄go individuālistu pasaules noliegšanu un uz sabiedrību orientēto pasaules pieñemšanu. Pamatā tas tika sasniegts ar radošo sintēzi, kas atspoguloja vienotības doktrīnu (tawhid). Agrīnā askētisma dihotomija par šo un nākamo pasauli pakāpeniska tika aizvietota ar antitēzi par Dievu un visu ārpus Dieva. Visu, ko Dievs ir radījis, it īpaši pasauli, bija nepieciešams pieņemt. Tieši šis aspekts iznīcināja askētisko uzskatu par pasauli un deva indivīdiem spēju "aizsniegt" Dievu. Pēc tā iekšēji vērsts pasaules misticisms kḷuva par vienu no vadošajiem spēkiem islāmā. ${ }^{22}$ Individuālisms bija pašos sūfisma pamatos. Sūfiju augstākās pieredzes uztveršana, nošķiršana no sevis fana'an al-nafs un pazušana Dievā (fana'fi allah) kḷuva par sevis noliegšanu sociālajā sfērā. ${ }^{63}$ Ar laiku šĩ individuālā iekšējās pasaules izzināšana tika arī papildināta ar Korāna un sunnas iekšējās nozīmes izzināšanu jeb "interpetācijas metodi no iekšienes [..] ko bieži dēvē par istinbāt jeb secinājumu”"64.

\footnotetext{
60 Korāns, 247, 408.

61 Sk.: Andras Hamori, "Ascetic Poetry (Zuhdiyyat)", in The Cambridge History of Arabic Literature: 'Abbasid Belles-Lettres, ed. Julia Ashtiany et al. (Cambridge: Cambridge University Press, 1990), 265-274.

62 Karamustafa, God's Unruly Friends, 64-65.

63 Ibid., 70.

64 Karamustafa, Sufism: The Formative Period, 2.
} 
Sūfiji jeb "Dieva draugi” bija viena no pirmajām islāma religiskām grupām, kura sāka lietot hašišu religiskās praksēs. Pirmās vēsturiskās liecības par hašišu un tā lietojumu novērotas stāstijjumos par persiešu ismailītu Haidaru. Tiek uzskatīts, ka Haidars, viens no sūfiju brālības dibinātājiem, atklāja hašišu ap 1155. gadu. Viens no az-Zarkaši stāstījumiem par Haidaru ir l̦oti îss, tomēr tas ieklauj skaistu un poētisku noskaņu: "Izmisumā Haidars aizgāja prom, vinam likās, ka viņš sāk atsvešināties no saviem biedriem. Ejot pa ceḷu, vinš ieraudzỉja kaņepes augu (hashīshah) un novēroja, ka auga ziedi šūpojās, neskatoties uz to, ka nebija vēja. Dziḷās pārdomās viņš saistija šo nedabisko parādību ar auga iekšējo noslēpumu. Pēc tam viņš norāva auga ziedus un apēda tos. Kad vinš atgriezās pie saviem biedriem, viņš sacīja viņiem, ka šis augs ietver noslēpumu." ${ }^{\prime 65}$

Haidars, līdzīgi kā agrīnie Indijas priesteri, ieteica saviem sekotājiem turēt noslēpumā šī dievišķāa auga īpašības. Neskatoties uz to, ka Haidars nebija pirmais, kurš atklāja kaņepes auga īpašības, viņš, iespējams, bija viens no pirmajiem cilvēkiem, kas izveidoja īpašo recepti šĩ auga lietošanai. Piemēram, al-Magrīzī un vairāki citi autori bieži vien atsaucās uz hašišu kā "Haidara vīnu"66.

Ahmets Karamustafa savā grāmatā God's Unruly Friends uzsver, ka sūfiju ordeņi, kuri balstījās šeiha Kalandara un šeiha Haidara mācībā, tika asi kritizēti par savu netradicionālo pieeju. Galvenokārt tāpēc, ka tai bija raksturīgas persiešu pirmsislāma tradicionālās iezīmes. Par to arī liecina 1359.-1360. gadā pieņemtais lēmums, kurš "aizliedza kalandariem skūt savas galvas un geerbties irāṇu un magu manierē. Sīrijā un Ėǵiptē no 13. līdz 14. gs. kalandari tika saskatīti galvenokārt kā irāṇu grupas sekotāji”'67.

Hašiša lietošanas izplatība sūfiju brālībās tiek apstiprināta ar vēlākām liecībām, kuras izceḷ to kā vienu no lielākajām islāma sabiedrības problēmām. Piemēram, viens no slavenākajiem 14. gs. islāma juridiskās skolas autoriem Ibn-Taimija izsaka lielas bažas par hašiša lietošanas izplatību galvenokārt sūfiju dēḷ. Cits autors saista hašiša mistisko lietošanu ar "kādu religiisko grupu, kura tika dibināta ap 500. g.". Šeit atsauce uz vārdu grupa (fiah) pamatā izcel sūfiju agrīnās saknes, iespējams, zoroastriešus. Haidara un Kalandara liecības izcel konkrēto laika posmu, kurā hašiša lietošana ienāk sūfiju tradīcijā, bet diemžēl šīs liecības nevar būt apstiprinātas vai noliegtas. ${ }^{68}$ Hašiša "atklāšana" neattiecas uz šiem cilvēkiem, kā arī tā lietošanas metodes varēja būt pārṇemtas no kādiem agrākiem avotiem. Tomēr tas neizslēdz faktu, ka tā lietošana netika popularizēta religiskos nolūkos. Kopumā agrāk pieminētais al-Ukbari stāstijums atspoguḷo

65 Rosenthal, op. cit., 183.

66 Ibid., 186.

67 Karamustafa, God's Unruly Friends, 126, 129-130.

68 Rosenthal, op. cit., 186. 
to, ka a) kaņepes pirms viña dzīves nebija plaši lietotas islāma sabiedrībā; b) kaņepes lietošanas prakse ir saistīta ar kādu no reliǵiskām kustībām, pie kuras Haidars vai viña brālība agrāk piederēja; c) kañepes lietošana ienāca islāma pasaulē no Indijas. ${ }^{69}$

16. gadsimtā turku reliǵiskā grupa, kura lietoja kaņepi, bija Abdalas Rumi grupa, kas kaņepes lietošanā pamatojās uz pravieti Eliju, vārdā Khidr jeb Khizr (zaļais). Abdaḷi ticēja, ka kañepes lietošana tiek atvasināta no agrīniem bibliskiem tēliem. Pravietis Ādams bija viens no svarīgākiem modeliem, kurš ietekmēja abdaļu reliǵiskās prakses. Abdalı izceḷ, ka, tā kā Ādams bija izdzīts no paradīzes kails, viņa ķermeni sedza vienīgi vīges lapa, kuru vinš̌ izmantoja, lai noslēptu savus dzimumorgānus. Kā arī abdaļi uzsver, ka Ādams izdzīvoja, ēdot tikai "zal̦ās lapas". Tāpēc vini uzturēja līdzīgu dzīvesveidu, staigājot puskaili, nosedzot sevi tikai ar tennure (simboliski - Ādama vīges lapa) un ēdot lielos daudzumos hašišu. Kailums simbolizē "virspusīga" kermeņa saplēšanu un pasaulīgo tukšumu. ${ }^{70}$ Savukārt hašiša lietošana deva sekotājiem iespēju atsvešināties no laika un telpas konceptiem un palīdzēja sasniegt apslēptās realitātes jēgu. Abdalıi uzskatīja, ka sejas un galvas mati nosedz "sejas atspulga" skaistumu, līdz ar to viņi vienmēr bija ar skūtām sejām un galvām. Viņi l̦oti cienīgi izturējās pret ēšanas paradumiem. Pēc maltītēm sekoja hašiša intoksikācija un muzikālā improvizācija (sama). Viñi parasti gulēja uz grīdas un tika modināti ar taures skaņu. Taures skaņa simbolizēja ercenggeli Israfilu: katrs rīts bija saistīts ar augšāmcelšanos. Abdaļi bija brīvi no visām valsts noteiktām reliǵiskām svinībām, jo viṇi nemaz netika uzskatīti par reālas pasaules iedzīvotājiem. ${ }^{71}$

Abdal̦i arī pielūdza Muhameda znotu Ali. Ali ir viens spilgtākajiem indivīdiem, kurš ietekmēja ismailītu skolas sekotājus, tajā skaitā hašasīnus. Bieži vien Abdalas Rumi piekritēji pat iegrieza Ali vārdu uz savas miesas. Miesas bojājums darbojās kā vizuāls atgādinājums par ḳermeña noliegšanu. ${ }^{72}$ Tas, ka abdal̦i lietoja hašišu islāmā, tradīcijas kontekstā tiek aprakstīts 16. gs. Džovanni Antonio Menavino darbā: "Pēc maltītes grupas vadītājs un viṇa biedri cēeās kājās. Pēc tam viṇi lūdz Dievu un skalāā balsī raud Allah kabul eyleye (lai Allāhs pieñem mūsu lūgšanu). Pēc lūgšanas atsevišķi jaunieši, kurus dēvē cuccegler, uz rokas paplātes pienes augu asseral (hašišu), kurš pēc ēšanas iedarbojās līdzīgi kā vīns. Kad visi piekritēji apēd hašišu, viṇi kopīgi turpina savus

69 Benedek Peri, "It is the Weed of Lovers: The Use of Cannabis Smoking among Turkic Peoples up to the 15th Century", Acta Orientalia Academiae Scientiarum Hung, Vol. 69.2 (2016): 142.

70 Vahīdī 1522. gadā apraksta Anatolijas abdalus šãdi: "Viņi valkā tikai vienu vilnas jostu. Uz viena pleca viņi tur zobenu un uz otra zizli (vāli). Uz krūškurvja vinniem ir divi mazie maisiņi, vienā viṇi tur žāvētas sūnas un tēraudu, kamēr otrā maisiñā tiek turēta kaņepe.” Ibid., 151.

71 Karamustafa, God's Unruly Friends, 216-217.

72 Heghnar Watenpaugh, "Deviant dervishes: Space, gender, and the construction antinomian piety in Ottoman Aleppo", International Journal Middle East Studies 37 (2005): 542-544. 
lasījumus."’33 Pēc lasījumiem, mūzikas un dejām viṇi nonāk ekstātiskā stāvoklī jeb "nāvē pirms nāves" stāvoklī.

Līdzīgas prakses tiek novērotas arī 16. gs. Bektaši dervišu grupās. Gadsimtiem ilgi vinuus dēvē par hašiša smēkēetājiem. Saskaņā ar šo tradīiju hašišs tika lietots ceremoniālos nolūkos ${ }^{74}$ Arī Bektaši tradīiijas dzeja bieži vien apraksta hašiša un opija lietošanu kā ceḷu uz svētību. Šie derviši uzskatija opija un hašiša noslēpumu par dvēseles kvintesenci (kaif). Tiek uzskatīts, ka ceremonijas laikā Bektaši apreibināja jaunos piekritējus, lai viņi nonāktu paradīzē un apstiprinātu savu ticību, dodot solījumus. ${ }^{75}$ Interesanti, ka slavenā 15. gs. Bektaši dzejnieka Kaigusuza Abdal vārds Kaigusuzs bija kā sinonīms terminam "hašišs". Šì iemesla dēl vairāki pētnieki interpretēja Kaigusuzu kā hašiša atkarīgo, kurš rakstīja savas dzejas, būdams smagi apreibināts. Kā piemēru mēs apskatīsim vienu no viṇa dzejām:

Šodien es redzēju, kā kaņepes augs uzkāpa uz zirga un aizjāja prom.

Tagad, kad viňš kļuva par dervišu, viņš vairs nekad nemelo.

Viņa apmetnis ir svētā Khizra apmetnis. Tas noved tevi pie Absolūtās Patiesības.

Tas ieveda manu prātu ekstāzes stāvoklī, kamēr es sasniedzu slepeno realitāti. ${ }^{76}$

\section{Hašiša sagatavošana} un tā lietošanas veidi lespējams, agrīnā islāma periodā tika uzrakstīts kāds îss traktāts, kas detalizēti aprakstīja hašiša sagatavošanas metodes un tās lietošanas veidus. Arī šādā gadijumā pastāv maza iespējamība, ka šãds darbs saglabātos līdz mūsdienām. Lielāka daļa tekstu fragmentu, kuri ir saglabājušies no vēlāka perioda, ir salīdzinoši abstrakti, kā arī tiem ir raksturīgi atšķiirīgi izcelšanās avoti ar dažādiem kontekstiem. ${ }^{77}$

Viens no pirmajiem autoriem, kurš ienes vērtīgu un korektu informāciju par hašiša sagatavošanu un lietošanas veidiem, ir Ibn al-Bajtārs (1197-1248). Pamatā vinš apraksta savus vērojumus Ēǵiptē. Viņš raksta, ka "personīgi ir redzējis, kā sūfiji lieto hašišu dažādos veidos. Daži no viniem kārtīgi izcep auga lapas, pēc tam uzmanīgi berž tās ar

73 Karamustafa, God's Unruly Friends, 219-221.

74 Refika Sarionder, "Mevlana Celaleddin Rumi and Hacı Bektaş Veli: Two Faces of Turkish Islam. Encounters, Orders, Politics", in Yearkbook of the Sociology of Islam, ed. Georg Stauth (Bielefeld: Transcipt, 2004), 64. Godfrey Goodwin, Private World of Ottoman Women (London: Saqi Books, 2013), 121.

76 Peri, op. cit., 144.

77 Detalizēts monogrāfiju saraksts par hašišu islāma tradīcijā ir atrodams darbā: Rosenthal, The Herb: Hashish versus Medieval Muslim Society, 138-151. Saraksts iekḷauj svarīgākos 13.16. gs. tekstus par hašiša kultūru islāmā. 
rokām līdz brīdim, kad neveidojas pasta, un beigās sarullē tās mazās tabletēs (aqrās). Citi dalıeji žāvē kaņepes ziedus, grauzdē tās, tad loba ar rokām, sajauc visu ar grauzdētām sezama sēklām un cukuru, tad ieliek tās mutē un ilgstoši košlā”̄78.

Al-Badrī darbs Kitāb Rāḥat al-arwāh fị l-ḥashīsh wa-l-rạh jeb "Dvēseles prieks hašišā un vīnā" ir viens no svarīgākiem 15. gs. abad literatūras avotiem. Al-Badrī atsaucās uz vairākiem medicīnas un juridiskiem darbiem, kuri diskutē par hašiša lietošanu, jau sākot ar 13. gadsimtu. Vienā no paragrāfiem viņš apraksta, kā kaņepes augs tika sagatavots pirms tā lietošanas. ${ }^{79}$ Balstoties uz al-Badrī teikto, var secināt, ka hašiša sagatavošanas metodes, kuras bija izplatītas Éğiptē un Sīrijā, pilnīgi iespējams, bija autentiskas. Ėğiptiešu metode ir šāda: tiek izlasîti septiņi apstrādāti kaņepes ziedi un viens neapstrādāts zieds, kurš darbojas kā ferments. Tad tos vāra līdz brīdim, kad ūdens sāk dzesēt liesmu. Pēc tam tos ieliek noslēgtās māla krūkās un sešas nedēlas glabā mitrā telpā, līdz tie sāk sadalīties. Septīto nedēļu tos mērcē ūdenī. Tad tos sasmalcina un izveido miltiem līdzīgu konsistenci. Pēc tam tiek veidotas mazas bumbiņas, kuras tiek turētas ēnā tik ilgi, kamēr tās izžūst. ${ }^{80}$ Tomēr, pēc al-Badrī domām, sīriešu izmantotā pagatavošanas metode ir vislabākā. Viṇi izžāvē kaņepes ziedus un trīs stundas sautē tos katlā. Pēc tam, kad vēlas taisīt "tabletes", viņi sajauc šo masu ar medu vai dateļu sīrupu.

Indiešu tradīcijā novērotas līdzīgas pagatavošanas metodes kā ēǵiptiešiem. Tomēr viņi bieži vien mēdza aizvietot neapstrādātos kaņepes ziedus ar kādām citām substancēm. Al-Badrī stingri nosoda šādu pagatavošanas praksi galvenokārt tāpēc, ka tā ietver rituālam neparedzētu (nešķistu) vielu, piemēram, govju mēslojuma un urīna vai menstruālo asiņu pievienošanu. Tiek uzskatīts, ka urīna lietošanu iedvesmojis dēmons Iblīss, ${ }^{81}$ kurš apmācīja indiešu šeihu Bīru Rantanu, kā kultivēt kaņepi un pagatavot hašišu. lespējams, šeihs Rantana arī bija pirmais, kas atklāja šĩ auga psihotropās īpašības. It īpaši ņemot vērā, ka al-Magrīzī un al-Badrī noraida bieži pieņemto pārliecību, ka hašiša sākotnējā lietošana islāma tradīcijā sākās ar šeihu Haidaru vai Kalandaru. Neatkarīgi no tā viņi bieži arī pieminēja, ka hašiša ēšanas ieradums islāma kultūrā ienāca no Indijas šaivisma rituāliem. ${ }^{82}$

Indiešu tradīcijā vērojamā sagatavošanas metode, šḳiet, ir nonākusi arī līdz Osmaņu impērijas laikiem. Līdzīga metode tiek arī novērota iepriekš pieminētajā Abdalas Rumi

\footnotetext{
78 Detalizēts monogrāfiju saraksts par hašišu islāma tradīcijā ir atrodams darbā: Rosenthal, The Herb: Hashish versus Medieval Muslim Societ., 189.

79 Marino, op. cit., 192.

80 Rosenthal, op. cit., 109.

81 Korānā "dēmons" Iblīss ir pieminēts kā "neticīgais". "Un, kad mēs teicām eñgel̦iem: "Krītiet pie zemes Ādama priekšā!", visi krita pie zemes, izṇemot Iblīsu. Vinš̌ atteicās, bija augstprātīgs un klıuva par neticīgo.” (2:34). Korāns, 17.

82 Marino, op. cit., 193.
} 
tradīcijā, galvenokārt Anatolijā. Metode ir šāda: "Ziemas un rudens beigās, kad sausie kaņepes ziedi ir zaudējuši savas īpašības un vairs nav lietojami, tiek veidots maisijums no iepriekš apstrādātiem ziediem ar kādu citu substanci. Attiecībā $9: 1$ ziedi tiek maisīti ar govju mēslojumu, kurš funkcionē kā ferments neapstrādāto kaņepju vietā. Viņi saka: "Ja mēs pieliekam mēslojumu fermentācijas masā, maisījums klūst viegls, ass un stiprs. Ja mēslojumu nepievieno, maisijums parasti kḷūst smags, rupjš un nelīdzens." Pēc tam viņi fermentē to ar urīnu un mērcē to ūdenī, kamēr maisījums sāk sadalīties un rodas tārpi. Ja tārpi nerodas ilgu laiku, maisījumā tiek izspiestas asinīs mērcētas lupatas. Tāda veidā viss tiek turēts līdz brīdim, kamēr visu ir pārņēmuši tārpi. Beigās viņi izsijā šo masu un glabā to ēnā, kamēr tā iž̌ūst." "83

Hašiša veidus mēdz noteikt pēc to nosaukuma. Lielākoties tās ir tabletes vai bumbiñas (qurs, tābah vai dugah - "lazdu rieksts"). Ir arī teiciens "taisīt tableti" (bandaqa bundugah). Gala produkts parasti izskatijās pēc hennas, tomēr hašišam bija l̦oti specifiska smarža, ko apraksta kā "aizraujošu un uzbudinošu". To parasti turēja kādā mazā kastītē (huggah) vai speciālā somiņā (kīs), protams, arī drēbju kabatās, aptinot to ar lakatu vai papīru. ${ }^{84}$

\section{Hašiša lietošana sūfiju rituālos}

Visi 13. gs. avoti par hašiša lietošanu rituālos tiek attiecināti uz sūfijiem (galvenokārt uz Kalandara un Haidara ordeña brālībām un uz 16. gs. dervišiem Abdalu Rumi, Bektaši). Rituālos hašiša lietošana galvenokārt ir saistīta ar ieiešanu transa stāvoklī (wajd). Hašišs tiek uzskatīts par palīglīdzekli, kurš noved indivīdu meditatīvā stāvoklī un palīdz cilvēka apziņai būt pilnīgā kontemplācijā par Dievu (fonā). Hanbāli tradīiijas priesteris Ibn al-Javzī (1126-1200) savā darbā Talbīs Iblīs (par herēzēm) piezīmē, ka daži sūfiji "aizvieto vīna intoksikācijas īpašības ar augu, ko dēvē par al-hashīsh, vai ar mikstūru al-majūn, kas nodrošina vinus ar īslaicīgu apziņas zaudēšanu" 85 .

L̦oti idealizēts apraksts par hašiša lietošanu rituālā ir atrodams al-Badrī darbā. levadu vinš iesāk ar šeiha Kalandara slavināšanu: "Tev ir jāzina, ka hašišu var lietot tikai inteliǵents, tikumīgs un zinošs indivīds. Ja tu vēlies lietot šo augu, lai attīīitu savu ķermeni un izprastu Dieva gudrību, tad tev sākumā ir nepieciešams lūgt palīdzību no pieredzējuša skolotāja, kurš pazīst šì auga noslēpumus. Būdams viņa klātbūtnē, paņem hašišu labajā rokā un saki: ${ }^{86}$ Slava mūsu Kungam Visu Augstākajam, kas visu radījis un

83 Rosenthal, op. cit., 191.

84 Ibid., 194-197.

85 Marino, op. cit., 194.

86 Rosenthal, op. cit., 203. 
izveidojis, kas nosaka liktenus un vada tos, kas ganībām liek zalot un vēlāk pārvērš tumšos rugājos. ${ }^{87}$ (87:1-4) Lai Dievs lūdzas par Muhamedu, patiesā ceḷa pravieti, un viña dievbijīgajiem cel̦abiedriem. Es zinu, ka Tu liecini gudrību caur savām radībām un ka Tu esi radījis šīm lietām pielietojumu. Tu esi atklājis savas radības noslēpumus tikai izvēlētiem cilvēkiem. Tu esi pilnveidojis šo augu ar savu gudrību un spēku un l̦āvi to pielietot savām radībām. Tādēl es Tevi lūdzu, l̦auj man būt sekmīgam, pielietojot šo augu, un nel̦auj man to darīt, ejot pret Tavu mīlestību. Tu l̦auj man atklāt lietas savā patiesajā dabā. Tu nodrošini mani ar šĩ auga gudrību un attālini mani no šaubām un vēlmēm. Tu, tas, kurš ir Visuvarens un Visuredzīgs." ${ }^{88}$ Rituāls turpinās ar hašiša ēšanu: "Viņš ieliek hašišu mutē un stipri košlā to, beigās uzdzerot pa virsu ūdeni vai kādu citu dzērienu, un lūdz Dievu. Tad viņš noskalo muti no hašiša paliekām, nomazgā seju un lēnā tempā sāk dziedāt "Dieva skaistuma" dziesmu (nagham), jo skaistums rodas lĩdz ar hašiša intoksikāciju (satlah). Zobos viņš ieberž antimonu, lai "rupjās dvēseles" (al-akhshān) neredz, kas ar viņu notiek. Mundrums nepamet vina prātu, un viņš ir mierīgs savā gaitā un sejas izteiksmē. Viņš ēd tikai smalku ēdienu un ir cildens savā runā. Vinš skatās uz skaistām sejām un sēž vispatīkamākajās vietās. Viņš vienmēr paliek ūdens avota tuvumā, pieredzējušu draugu kompānijā. Viñš sāk reflektēt par iemeslu un par lietām, kuras to rada; par darītāju un izdarīto; par notikumiem un sekām; par runātāju un runu; par darbības cēloņiem. Šādā stāvoklī, uztverot redzēto un tā nozīmi, Dieva mūžǐgā gudrība un Viña absolūtā žēlastība emanē uz viņu un atklāj lietu patieso saturu. Viņš redz cilvēku sirdis ar acīm un kontrolē acis caur tām. Viņš nošķiras no idejas par cilvēcību un ieplūst idejā par dievišķību. Vārds, ar ko nabadzīgie tiek identificēti (nistab al-fugarā), ieplūst viņa realitātē un kḷ̂ust likumīgs, un viņš sasniedz svētības pilnību (tawfïg)." ${ }^{99}$

Šis rituāls labi atspogul̦o mistisko pasauli, kura tiek radīta caur uzticīgiem sūfiju piekritējiem. Nobeigumā šeihs Haidars brīdina par nepareizo hašiša lietošanu un aizliedz atklāt tā mistiskās īpašības sabiedrībā, protams, izņemot sūfijus. Neskatoties uz to, hašiša ēšana ārpus sūfiju mistiskās tradīcijas kḷuva arī izplatīta sabiedrībā. Par to liecina arī valsts noteiktie regulējumi, piemēram, nodoḳ̣li par hašiša lietošanu. Pastāv vairāki faktori, kas ietekmēja hašiša izplatību. Pirmkārt, hašišs bija l̦oti lēts, tādēl to baudīt varēja visa sabiedrība. Otrkārt, hašišu bija l̦oti viegli nēsāt līdzi, kā arī to bija viegli paslēpt. Treškārt, hašiša ēšana bija mazāk aizdomīga nekā alkohola dzeršana galvenokārt tāpēc, ka tā neradīja smaku un līgošanos..$^{90}$ Ceturtkārt, hašiša lietošana nebija konfliktā ar Korānu.

87 Korāns, 620.

88 Rosenthal, op. cit., 203-204.

89 Ibid., 205.

90 Marino, op. cit., 194. 
Kā jau iepriekš minēts, islāma juristiem bija ļoti dažādas domas par hašiša lietojuma iekḷaušanu rituālos vai sabiedrības ikdienā. Tomēr viens no spilgtākajiem hašiša ienaidniekiem bija tas pats Ibn Taimija. Lai gan Taimija bija nozīmīgs sūfiju tradīcijā, viņa attieksme pret hašišu vienmēr bija noraidoša. Diskusijā par kaņepes rituālo nešķištību (najāsa) Hanbalī tradīcijas jurists Taimija izcel trīs argumentus: a) hašišs nav rituāli "netīrs" augs (najs); b) tikai šķidra satura (māi) hašišs ir neškīsts, kamēr cietā veidā to var lietot (tāhir); c) balstoties uz Taimijas personīgo viedokli, hašišs ir nešķīsts, līdzīgi kā raudzētie dzērieni no vīnu sulas (kharm); hašišam ir nepieciešams būt aizliegto substanču sarakstā (khabāith). Kā jau iepriekš teikts, ja vīns ir nešķ̄ists kā urīns, tad hašišs ir tikpat netîrs kā mēslojums. Līdz ar to hadd juridiskās sankcijas tika attiecinātas uz hašiša ēdājiem tikpat stingri kā uz vīna dzērājiem. Kopumā Ibn Taimija bija vairāk satraukts par hašiša fiziskajiem un prātu ietekmējošajiem efektiem jeb, kā viņ̌̌ to sauc, - "nelikumīgo baudu" (al-hazz al-muharram). Viņš uzskatijja, ka hašiša lietošana atspoguḷo indivīda apzināto gribu apmierināt savas hedoniskās vēlmes. Piemēram, kontemplāciju par skaistām sejām un seksuālām baudām vai dziedāšanu un dejošanu. Šādā gadījumā hašišam ir jābūt aizliegtam, jo tas novērš cilvēka uzmanību no dhikr Allāh (Allāha pieminēšana). Taimija uzskatīja, ka hašišs ir īpaši bīstams tāpēc, ka tas spēj stimulēt indivīda iztēli un radīt netiklas ilūzijas. ${ }^{91}$

Islāma sabiedrībā sūfiju mūzika, kura pakāpeniski paātrina dziesmas un dejošanas ritmu rituālu laikā, tika saskatīta kā netradicionāla prakse. Neskatoties uz to, ka sūfiju prakses mēdza būt salīdzinoši radikālas pārējo islāmticīgo skatījumā, viṇi nekad neapšaubija to efektivitāti. Piemēram, Abdala Rumi, Kalandars un Haidars bieži organizēja publiskus pasākumus, kuros mūzika un deja bija viena no svarīgākajām rituāla sastāvdal̦ām. Brīnišķīgā veidā to atspoguḷo 16. gs. glezna, kurā sūfiju pulcēšanās laikā gan eņgelı̣i, gan cilvēki priecīgi dejo, būdami apreibināti. Gleznas kreisajā stūrī sēž trīs Kalandara derviši, kuri spēlē mūziku un aplaudē ritmā. Šādas prakses ieklı̣āva arī hašiša lietošanu pirms rituāla sākuma. ${ }^{92}$ Hašiša iedarbība piešḳīra saasināto skaņas izjūtu, tāpēc arī mūzikas un dziedāšanas efektivitāte likās ārpasaulīga un izcili skaista. ${ }^{93}$

Tomēr arī negatīva hašiša ietekme uz prātu nekad netiek aizmirsta diskusijās par tā fizikālo un religíisko iedarbību. Savā ziņā tas ir viens no slavenākajiem un biedējošākajiem hašiša lietošanas aspektiem. Tā lietošana bieži tika asociēta ar atkarīgā indivīda nenormālo uzvedību. Bieži vien šāda mentālā nestabilitāte bija īslaicīga, tomēr vairākos gadījumos tā radīja hroniskas izmaiņas cilvēka identitātē. Par to arī liecina bieži

91 Marino, op. cit., 195.

92 Karamustafa, God's Unruly Friends, 66-67.

93 Rosenthal, op. cit., 214. 
pieminēts arābu vārds tughayyir al-agl ("tas, kas maina prātu") jeb tughayyib ("attālina" cilvēku no realitātes). ${ }^{94}$

Mediķi un pētnieki bieži apraksta šīs substances negatīvo efektu uz cilvēka mentālo un fizisko veselību. Al-Zarkaši savās piezīmēs apraksta šādus simptomus: acu apsārtums, sausa mute, pārmērīga gulēšana un smagums galvā, kā arī ekstremitāšu tirpšana. Ilgstoša lietošana samazina vīrieša potenci un seksuālo vēlmi. Pasliktina redzi. Hašišs izraisa slinkumu, vājumu, sliktu elpu. letekmē indivīda realitātes uztveri un izraisa hroniskas ilūzijas. ${ }^{95}$ Galvenā sociālā problēma bija tā, ka pārmērīga hašiša lietošana izraisija atkarību. Savukārt atkarība saskaņā ar tradicionālā islāma teoloǵiju ir grēks, jo katrs musulmanis ir atbildīgs Dieva un sabiedrības priekšā. Tādējādi musulmaņa identitāte cieši balstās sabiedrībā dominējošā viedoklī. šādā gadijumāa atkarība var būt izprasta divos veidos: a) jurm jeb atkarība kā noziegums; b) mard ruhani jeb atkarība kā garīga slimība. ${ }^{96}$ Tomēr šajā darbā mēs neiedziļināsimies teologiiskajā diskusijā par atkarību islāma sabiedrībā.

\section{Secinājumi}

Mūsdienu islāma pasaulē turpinās asas debates par ortodoksālā islāma un sūfisma tradīciju atšķiirībām. Sūfisms tiek vairāk identificēts ar tautas reliǵiozitātei raksturīgām rituālpraksēm un nevis ar formālām doktrinālām idejām, tomēr šīs tradīijas pamatideja ir vienošanās ar Dievu. Šĩ mistiskā vienošanās ar Dievu bieži vien izslēdz cilvēkam raksturīgo racionālo izpratni par religiju. Tā ir dziļa sūfiju mistiķa iekšējā pieredze, kura iziet ārpus materiālās pasaules izpratnes. Līdz ar to šis raksts dal̦̄eji atspoguḷo, kā varētu interpretēt sūfisma piekritēju pieredzi ar cilvēkam izprotamiem, zinātniski korektiem terminiem. Terminiem sūfisms un sūfijs ir daudzi nozīmju slāñi, ar tiem apzīmē islāma reliǵiskās dzīves radošās manifestācijas. Gadsimtu garumā ar sūfismu tiek saistītas netradicionālas pieejas islāma religiskajai dzīvei. Citiem vārdiem, sūfisms funkcionēja, lai atdzīvinātu musulmaņa reliǵisko dzīvi caur individuālo vienošanos ar Dievu, kas ortodoksālā islāmā bieži vien tika aizmirsts. ${ }^{97}$

\footnotetext{
94 Rosenthal, op. cit., 226.

95 Hanas, op. cit., 829.

96 Mansur, Perspectives on Drug Addiction in Islamic History and Theology, 918-921.

97 Babli Parveen, "The Eclectic Spirit of Sufisms in India: An Appraisal”, Social Scientists, Vol. 42, No. 11/12 (Nov.-Dec. 2014): 39.
} 
Research of psychedelic drug use in Islam shows a new perspective on the theological aspects of this religion and indicates its syncretic manifestations, especially in Sufi tradition. This paper mainly answers two questions: a) how the use of cannabis and hashish is reflected in Sufi tradition; b) how Sufis followers include the use of psychedelic drugs in their spiritual practices. The paper mostly covers the $10^{\text {th }}$ to the $16^{\text {th }}$ century $A D$. It reflects how the use of hashish in Sufism is connected to local Islamic tradition beliefs.

In today's Islamic world, there is a heated debate about the differences between the traditions of orthodox Islam and Sufism. Sufism is rather identified with the ritual practices of the nation's religiosity than with formal doctrinal ideas, but the basic idea of this tradition is the individual's unification with God. This mystical unification with God often precludes a person's rational understanding of religion. It is a deep inner experience of a Sufi mystic that transcends the understanding of the material world. Thus, this article partly explores how the experience of Sufi supporters could be interpreted in humanly understandable, scientifically correct terms. The terms "Sufism" and "Sufi" have many layers of meaning, denoting the creative manifestations of Islamic religious life. For centuries, non-traditional approaches to Islamic religious life have been associated with Sufism. In other words, Sufism functioned to revive the religious life of a Muslim through an individual unification with God, in many cases frequently forgotten by orthodox Islam. 